\title{
Phylogenetic analysis of the major capsid protein gene of iridovirus isolates from cultured flounders Paralichthys olivaceus in Korea
}

\author{
Jeong Wan Do ${ }^{1}$, Seung Ju Cha ${ }^{2}$, Jong Su Kim ${ }^{2}$, Eun Jeong $\mathrm{An}^{2}$, Nam Sil Lee ${ }^{1}$, \\ Hee Jung Choi ${ }^{1}$, Chan Hwei Lee ${ }^{1}$, Mi Seon Park ${ }^{1}$, Jin Woo Kim ${ }^{1}$, Yi Cheong Kim ${ }^{1}$, \\ Jeong Woo Park ${ }^{2, *}$
}

${ }^{1}$ Pathology Division, National Fisheries Research \& Development Institute, Kijang, Busan 619-902, Korea
${ }^{2}$ Department of Biological Sciences, University of Ulsan, Ulsan 680-749, Korea

\begin{abstract}
In 2003, 13 isolates of iridovirus were obtained from cultured flounders Paralichthys olivaceus during epizootics in Korea. The full open reading frames (ORFs) encoding the major capsid protein (MCP) (1362 bp) from the 13 flounder iridoviruses (FLIVs) were sequenced and the deduced amino acid sequences were phylogenetically analyzed. Phylogenetic analysis of the MCP revealed that all 13 FLIVs were the same species as rock bream iridovirus (RBIV), red sea bream iridovirus (RSIV), and infectious spleen and kidney necrosis virus (ISKNV), and were grouped into an unknown genus which was different from the 2 genera known to infect fish, Ranavirus and Lymphocystivirus. This is the first report on the isolation and phylogenetic analysis of the iridovirus of unknown genus from flounders during epizootics.
\end{abstract}

KEY WORDS: Iridovirus $\cdot$ Flounder $\cdot$ Major capsid protein $\cdot$ MCP

\section{INTRODUCTION}

Iridoviruses are large cytoplasmic DNA viruses with an icosahedral morphology (Williams 1996); the family Iridoviridae consists of 4 genera including Iridovirus, Chloriridovirus, Ranavirus, and Lymphocystivirus. Iridoviruses infect a wide variety of cultured fish (Wolf 1988, Hetrick \& Hedrick 1993). According to the International Committee on Taxonomy of Viruses (ICTVdB) (www.ncbi.nlm.nih.gov/ICTVdb/ICTVdB/), fish iridoviruses are members either of the genus Lymphocystivirus or Ranavirus. While iridoviruses belonging to the genus Lymphocystivirus cause the development of clusters of extremely hypertrophied fibroblasts called lymphocystis cells, other iridoviruses belonging to the genus Ranavirus cause systemic diseases in infected animals and are associated with high morbidity and mortality (Ahne et al. 1989, Eaton et al. 1991, Hedrick \& McDowell 1995, Hedrick et al. 1992, Langdon et al. 1986, 1988, Moody \& Owens 1994, Pozet et al. 1992). However, a taxonomic analysis of putative proteins suggests the presence of fish iridoviruses which belong neither to the genus Ranavirus nor to the genus Lymphocystivirus (He et al. 2001, Hyatt et al. 2000, Do et al. 2004). In addition, genetic and phenotypic variants within iridoviruses (Goldberg et al. 2003, Hyatt et al. 2000, Williams \& Cory 1993) suggest the possibility of the presence of diverse variants within the fish iridoviruses.

Iridoviral epizootics have occurred recently among various kinds of cultured fish in Korea (Jung \& Oh 2000, Kim et al. 2002, Do et al. 2004). In 2003, iridoviral epizootics occurred in flounders cultured in the southern part of the Korean peninsula and 13 iridoviruses were isolated from cultured flounders. In the present study, we compared the amino acid sequences of the major capsid protein (MCP) of 13 flounder iridoviruses (FLIVs) to those of other iridoviruses. Our data revealed that all of the 13 FLIVs were the same species as rock bream iridovirus (RBIV), red sea bream irido- 
virus (RSIV), and infectious spleen and kidney necrosis virus (ISKNV) and were classified into a new genus, cell hypertrophy iridoviruses, proposed by He et al. (2001).

\section{MATERIALS AND METHODS}

Viruses. In 2003, epizootics occurred among juvenile of flounders cultured in the southern part of the Korean peninsula, and losses of up to $80 \%$ on affected farms were recorded. Thirteen iridoviruses were obtained from moribund flounders ( 3 to $11 \mathrm{~g}$ ) cultured at 13 different fish farms located in 5 different regions of Korea (Fig. 1). Sources of the fish iridoviruses used in this study are listed in Table 1.

Histological examination. After external examination, an anatomical examination was carried out, and tissue samples from the kidney, spleen, liver, and gill were fixed with Bouin's solution. Fixed tissues were dehydrated in alcohol (70 and approx. 100\%) and were embedded in paraffin. Tissue sections $(4 \mu \mathrm{M}$ thick) were stained with Harris' hematoxylin and eosin (H\&E) solution and then examined with a light microscope (Carl Zeiss).

Ultra structural examination. Small pieces of spleen were fixed with $2.5 \%$ glutaraldehyde in phosphate buffer ( $\mathrm{pH} 7.2$ ) at $4^{\circ} \mathrm{C}$ for $4 \mathrm{~h}$, and post-fixed with $1 \%$ osmium tetroxide in phosphate buffer $(\mathrm{pH} 7.2)$ at room temperature for $2 \mathrm{~h}$. After post-fixation, cells were

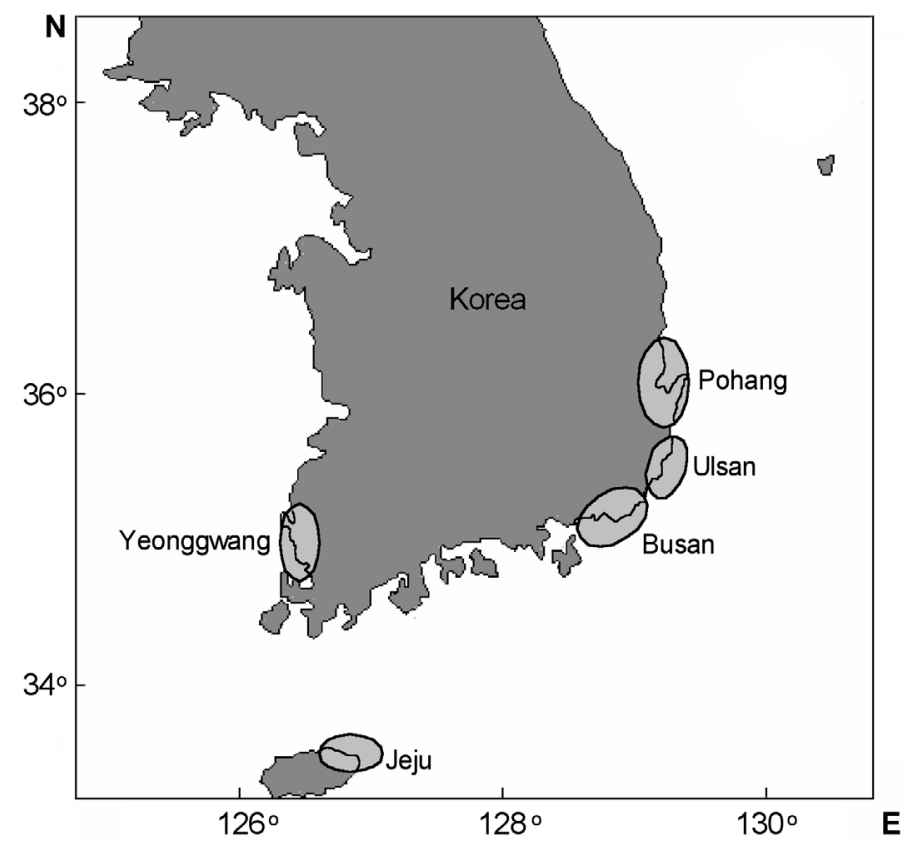

Fig. 1. Location of fish farms where epizootics occurred and iridoviruses were isolated
Table 1. Sources of iridoviruses isolated from cultured flounders in Korea. FLIV: flounder iridovirus. Letters after geographical regions are fish farm initials

\begin{tabular}{lccl} 
Isolate & $\begin{array}{c}\text { Body weight } \\
\text { of flounder }(\mathrm{g})\end{array}$ & $\begin{array}{c}\text { Date } \\
(\mathrm{y} / \mathrm{mo})\end{array}$ & $\begin{array}{l}\text { Geographic region of } \\
\text { fish farm (Korea) }\end{array}$ \\
\hline FLIV-DS1 & $3-4$ & $2003 / 11$ & Ulsan DS \\
FLIV-DS2 & $4-5$ & $2003 / 12$ & Ulsan DS \\
FLIV-EJ & $6-7$ & $2003 / 10$ & Busan EJ \\
FLIV-JJ & $6-7$ & $2003 / 11$ & Jeju \\
FLIV-JHJ & $6-7$ & $2003 / 11$ & Jeju JHJ \\
FLIV-JJY & $6-7$ & $2003 / 11$ & Jeju JJY \\
FLIV-JSY & $6-7$ & $2003 / 11$ & Jeju JSY \\
FLIV-MI & $3-4$ & $2003 / 11$ & Busan MI \\
FLIV-PH & $6-7$ & $2003 / 10$ & Pohang \\
FLIV-SS & $7-11$ & $2003 / 11$ & Ulsan SS \\
FLIV-WD1 & $6-7$ & $2003 / 10$ & Ulsan WD \\
FLIV-WD2 & $7-11$ & $2003 / 11$ & Ulsan WD \\
FLIV-YG & $6-7$ & $2003 / 11$ & Yeonggwang \\
\hline
\end{tabular}

dehydrated in ethanol and embedded in Epon 812. Thin sections were cut by an ultramicrotome (LKB), stained with uranyl acetate and lead citrate solution, and observed with a JEOL 1200 EX-2 transmission electron microscope (TEM).

PCR amplification of the MCP gene. The MCP genes of iridovirus were amplified from virus-infected spleen DNA using PCR. Spleen from infected fish was homogenized in a lysis buffer (4 M urea, $200 \mathrm{mM}$ Tris, $20 \mathrm{mM} \mathrm{NaCl}, 200 \mathrm{mM}$ EDTA, pH 7.4). After centrifugation at $1700 \times g$ for $10 \mathrm{~min}$, the supernatant was treated with proteinase $\mathrm{K}\left(0.2 \mathrm{mg} \mathrm{ml}^{-1}\right)$ and sarcosyl $(1 \%)$ at $45^{\circ} \mathrm{C}$ for $3 \mathrm{~h}$, followed by phenol/chloroform extraction and ethyl alcohol precipitation. The genomic DNA in the pellet was dissolved in TE (10 mM Tris$\mathrm{HCl}$ and $1 \mathrm{mM}$ EDTA, pH 7.5) and used as a template for PCR. PCR primers were designed from nucleotide sequences of the MCP of rock bream iridovirus (RBIV) (AY532606, Do et al. 2004) and lymphocystis disease virus K1 (LCDV-K1) (AY303804) (Table 2). The gene amplification reaction conditions were as follows: 1 cycle of $94^{\circ} \mathrm{C}$ for $5 \mathrm{~min} ; 35$ cycles of $92^{\circ} \mathrm{C}$ for $30 \mathrm{~s}$, $58^{\circ} \mathrm{C}$ for $1 \mathrm{~min}$, and $72^{\circ} \mathrm{C}$ for $1 \mathrm{~min}$; and 1 cycle of $72^{\circ} \mathrm{C}$ for $5 \mathrm{~min}$. The amplified PCR products were cloned into a pGEM-T vector (Promega), and sequencing was performed at the Immunomodulation Research Center, Korea, on an automatic DNA sequencer (Applied Biosystems) according to the dye terminator procedure with forward and reverse primers and overlapping primers designed from the sequencing results.

DNA sequence analysis. The DNA and the deduced amino acid sequences were compared with the GenBank/EMBL databases using the basic local alignment search tool (BLAST). Sequences were aligned using CLUSTAL W (Thompson et al. 1994), after which the phylogenetic tree was constructed with TreeView 
Table 2. PCR primers used in gene amplification. LCDV: lymphocystis disease virus; RBIV: rock bream iridovirus; F: forward primers; $\mathrm{R}$ : reverse direction primers. $\mathrm{p}$ : primer for partial open reading frame (ORF) amplication; f: primer for full length ORF amplication

\begin{tabular}{|lll|}
\hline Virus & Primer & \multicolumn{1}{c|}{ Sequence } \\
\hline LCDV & LCDV-pMCP-F & 5'-TTGACAGCAGGCGATTTAGA-3' \\
& LCDV-pMCP-R & 5'-GCAATTCCACCGTCAAAGAT-3' \\
RBIV & RBIV-pMCP-F & 5'-GAGGAGGTGTCGGTGTCATT-3' \\
& RBIV-pMCP-R & 5'-GGCATAGTCTGACCGTTGGT-3' \\
& RBIV-fMCP-F & 5'-GAAAAACGAGGCCGATCATA-3' \\
& RBIV-fMCP-R & 5'-TACGCTATGGCCACAATTCA-3' \\
& & \\
\hline
\end{tabular}

FLIV-JSY, AY633989; FLIV-JJY, AY633990;

FLIV-JHJ, AY633991; FLIV-PH, AY633992).

\section{RESULTS AND DISCUSSION}

In 2003, wide spread epizootics occurred among juvenile flounders cultured at 13 fish farms located in 5 different regions in Korea (Fig. 1, Table 1). The net losses in affected populations were up to $80 \%$. The diseased fish were lethargic and showed severe anemia, petechiae of gills, abdomi-

(Page 1996). The phylogenetic relationships among species were determined using the neighbor-joining method (Saitou \& Nei 1987) and the reliability of the NJ tree was inferred using the Felsenstein (1985) bootstrap method with 1000 replicates

Nucleotide sequence accession number. The following nucleotide sequence data reported in this paper were deposited in the GenBank (GenBank accession numbers: FLIV-DS1, AY633980; FLIV-DS2, AY633981; FLIV-MI, AY633982; FLIV-SS, AY633983; FLIV-YG, AY633984; FLIV-WD2, AY633985; FLIV-WD1, AY633986; FLIV-EJ, AY633987; FLIV-JJ, AY633988; nal distension, and enlargement of spleens. Histopathology revealed hypertrophied heteromorphic cells in the spleens, kidneys, and gills. Parasites and bacteria were not consistently recovered from the organs of the diseased fish. Electron microscopic observation of an ultrathin section of the spleens of the diseased fish revealed the presence of cytoplasmic inclusion body that displaced the nucleus to the periphery of the cell. The marginally located nucleus was irregular in shape. Within the inclusion body, both complete and incomplete icosahedral nucleocapsids were observed. The size of virus particles
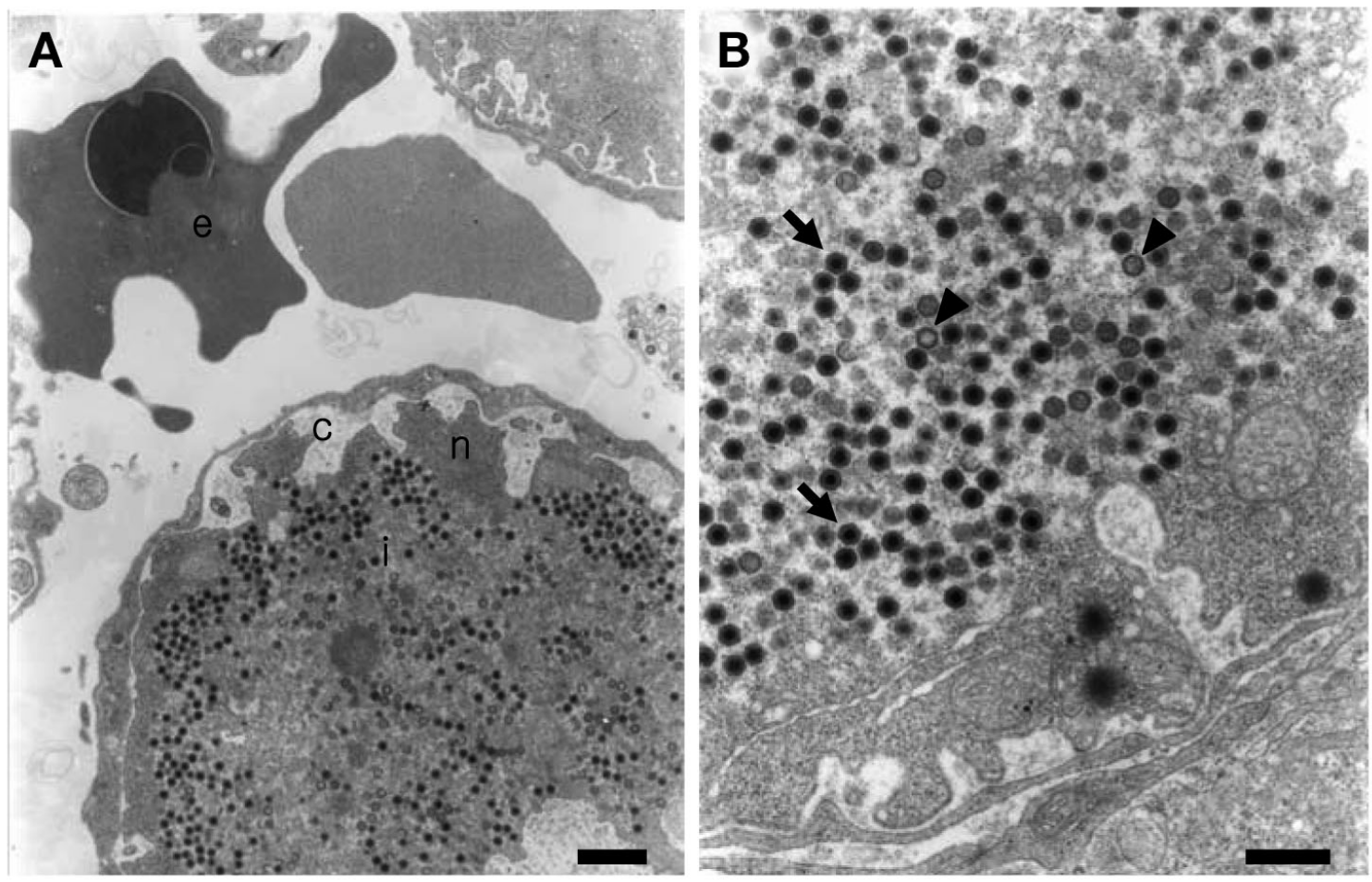

Fig. 2. Paralichthys olivaceus. Transmission electron micrographs of virus particles in cells of spleen from diseased flounders. (A) Virus particles in an inclusion body within the cytoplasm (bar $=1 \mu \mathrm{m}$ ). (B) A high magnification of virus particles in an inclusion body (scale bar $=500 \mathrm{~nm}$ ). Arrows and arrowheads indicate complete and incomplete nucleocapsids, respectively. c: cytoplasm of host cell; e: erythrocyte; i: inclusion body; n: nucleus of host cell 


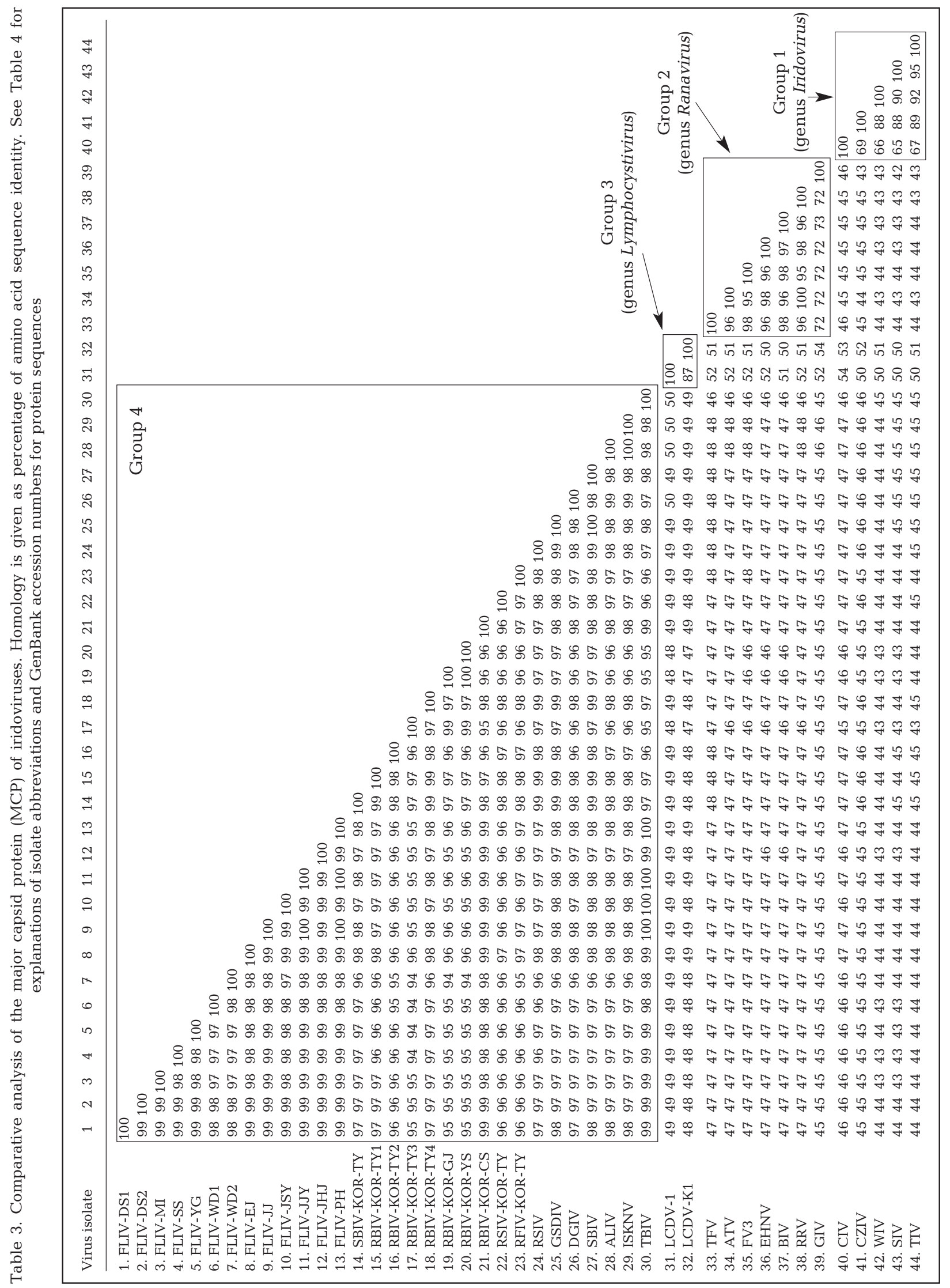


measured from vertex to vertex was about $140 \mathrm{~nm}$ (Fig. 2). All observations coincided with the characteristics of iridoviral diseases.

The family Iridoviridae consists of 4 genera: Iridovirus, Chloriridovirus, Ranavirus and Lymphocystivirus (Willis, 1990). There have been many reports of iridoviral infection in flounders, and their causative agents have been identified as lymphocystiviruses, which are members of the genus Lymphocystivirus (Darai et al. 1983, Tidona \& Darai 1997). To determine whether or not the causative agent of the epizootics among flounder cultured in Korea is the lymphocystivirus, PCR was performed using PCR primers specific for the MCP of LCDV designed from the nucleotide sequences in GenBank (AY303804) (Table 2). However, we could not amplify the MCP gene of LCDV from any of the spleen samples collected from the 13 fish farms (data not shown).

Wide-spread epizootics have occurred recently among various species of cultured fish, such as rock bream Oplegnathus fasciatus, red sea bream Chrysophrys major, sea bass Lateolabrax japonicus, and rockfish Sebastes schlegeli in Korea and we found that a new genus, cell hypertrophy iridoviruses, was the causative agent of the epizootics of iridoviral diseases there (Do et al. 2004). Thus, in order to amplify partial open reading frames (ORF) of MCP, PCR primers, RBIVpMCP-F and RBIV-pMCP-R, were designed from the nucleotide sequences of the MCP of a Korean isolate, RBIV (AY532606) (Do et al. 2004) (Table 2), and PCR was performed to detect the presence of the iridovirus of the new genus. We found that the PCR amplified the MCP gene in all of the 13 spleen samples collected from the 13 fish farms (data not shown).

In order to determine the genetic characteristics of the 13 FLIVs, a full-length ORF of the MCP of the 13 FLIVs was amplified by PCR. PCR primers, RBIV-fMCP-F and RBIV-fMCP-R, were designed from the nucleotide sequences in the GenBank nucleotide sequence database of RBIV (AY532606) (Table 2). Here we used the PCR to directly amplify the MCP DNA sequences from uncultured (frozen) spleen obtained from moribund fish in order to avoid any random genetic changes accumulated during viral passage in cell cultures. The PCR products were cloned into a pGEM-T vector and the nucleotide sequence of the cloned DNA fragments was determined by using M13 forward and M13 reverse sequencing primers in the vector and internal sequencing primers. Every nucleotide position in the MCP gene was determined at least twice from each
DNA strand. The MCP ORF was 1362 bp in length and codes for a protein of 453 amino acids.

To determine the relationship between the 13 FLIVs and previously reported iridoviruses, we compared the full amino acid sequences of the MCP of 13 FLIVs to those of 31 other iridoviruses available in GenBank including Chilo iridescent virus (CIV, typespecies of the genus Iridovirus), FV3 (type-species of genus Ranavirus), and LCDV-1 (type-species of genus Lymphocystivirus). As shown in Table 3 (see Table 4 also), the 13 FLIVs showed 97 to $100 \%$

Table 4. Viral isolates and GenBank accession numbers for protein sequences in Table 3 and Fig. 3

\begin{tabular}{|c|c|}
\hline Virus isolate & $\begin{array}{c}\text { GenBank } \\
\text { accession no. }\end{array}$ \\
\hline ALIV, African lampeye iridovirus & AAP37442 \\
\hline ATV, Ambystoma tigrinum virus & AAP33191 \\
\hline BIV, Bohle iridovirus & AAO32316 \\
\hline CIV, Chilo iridescent virus & NP_149737 \\
\hline CZIV, Costelytra zealandica iridescent virus & O39164 \\
\hline DGIV, Dwarf gourami iridovirus & AAP37441 \\
\hline EHNV, Epizootic haematopoietic necrosis virus & AAO32315 \\
\hline FLIV-DS1, Flounder iridovirus & AY633980 \\
\hline FLIV-DS2 & AY633981 \\
\hline FLIV-EJ & AY633987 \\
\hline FLIV-JJ & AY633988 \\
\hline FLIV-JHJ & AY633991 \\
\hline FLIV-JJY & AY633990 \\
\hline FLIV-JSY & AY633989 \\
\hline FLIV-MI & AY633982 \\
\hline FLIV-PH & AY633992 \\
\hline FLIV-SS & AY633983 \\
\hline FLIV-WD1 & AY633986 \\
\hline FLIV-WD2 & AY633985 \\
\hline FLIV-YG & AY633984 \\
\hline FV3, frog virus 3 & Q67473 \\
\hline GIV, grouper iridovirus & AAM00286 \\
\hline GSDIV, grouper sleepy disease iridovirus & AAP37443 \\
\hline ISKNV, infectious spleen and kidney necrosis virus & NP_612228 \\
\hline LCDV-1, lymphocystis disease virus 1 & NP_044812 \\
\hline RBIV-KOR-CS, rock bream iridovirus & AY532611 \\
\hline RBIV-KOR-GJ & AY532609 \\
\hline RBIV-KOR-TY1 & AY532606 \\
\hline RBIV-KOR-TY2 & AY533035 \\
\hline RBIV-KOR-TY3 & AY532067 \\
\hline RBIV-KOR-TY4 & AY532608 \\
\hline RBIV-KOR-YS & AY532610 \\
\hline RFIV-KOR-TY, rockfish iridovirus & AY532614 \\
\hline RRV, Regina ranavirus & YP_003785 \\
\hline RSIV, red sea bream iridovirus & BAC66968 \\
\hline RSIV-KOR-TY & AY532612 \\
\hline SBIV, sea bass iridovirus & BAC77297 \\
\hline SBIV-KOR-TY & AY532613 \\
\hline SIV, Simulium iridescent virus & P22166 \\
\hline TBIV, turbot iridovirus & BAD12494 \\
\hline TFV, Tiger frog virus & NP_572010 \\
\hline TIV, Tipula iridescent virus & P18162 \\
\hline WIV, Wiseana iridescent virus & O39163 \\
\hline
\end{tabular}


amino acid sequence identity to each other and 94 to $100 \%$ identity to 17 iridoviruses such as SBIV-KOR-TY (sea bass iridovirus), RBIV-KORTY1，RBIV-KOR-TY2，RBIV-KOR-TY3, RBIV-KOR-TY4, RBIV-KOR-GJ, RBIVKOR-YS, RBIV-KOR- CS, RSIV-KORTY, RFIV-KOR-TY (rockfish iridovirus), RSIV, GSDIV (grouper sleepy disease iridovirus), DGIV (dwarf gourami iridovirus), SBIV, ALIV (African lampeye iridovirus), ISKNV, and TBIV (turbot iridovirus). The high degree of sequence identity suggests that the 13 FLIVs are the same species as the other 17 iridoviruses. However, the 13 FLIVs showed 46 to $49 \%$ amino acid sequence identity to 3 type-species: $46-47 \%$ to CIV, $47 \%$ to FV3, and $49 \%$ to LCDV-1 (see Table 4 for viral isolate abbreviation explanations and GenBank accession numbers). In the MCP tree, the iridoviruses used in the multiple alignments were subdivided into 4 groups: group 1, iridoviruses including CIV; group 2, ranaviruses including FV3; group 3, lymphocystiviruses including LCDV-1; group 4, unassigned viruses which did not include any of the 3 type species (Fig. 3A). Hyatt et al. (2000) have suggested the presence of 2 groups of iridoviruses, erythrocytic iridoviruses and cell hypertrophy iridoviruses, which are not closely related to any of the known genera. Our MCP tree result supports the presence of a new genus in the family Iridoviridae, and the members of group 4 may belong to a new genus, tentatively referred to as the cell hypertrophy iridoviruses (He et al. 2001). All the 13 FLIVs clustered within group 4 (Fig. 3A). These findings indicate that all the flounder isolates were members of the new genus, cell hypertrophy iridoviruses, and that this new genus may be responsible for the epizootics of iridoviral diseases in flounders in Korea.

In 2000 and 2002 we isolated 10 iridoviruses from rock bream, red sea bream, rockfish, and sea bass. Even though all the iridoviruses isolated from cultured fish in Korea were grouped into a new genus, cell hypertrophy iridoviruses, multiple strain variants existed among the iridoviruses, based on amino acid sequence variation (data not shown). Thus, we reexamined the phylogenetic positions of the 13 iridoviruses from flounders in Korea by comparing the full-length 453 amino acid sequences of the MCP of the 13 isolates with those of the previously isolated 10 Korean isolates and other iridoviruses within

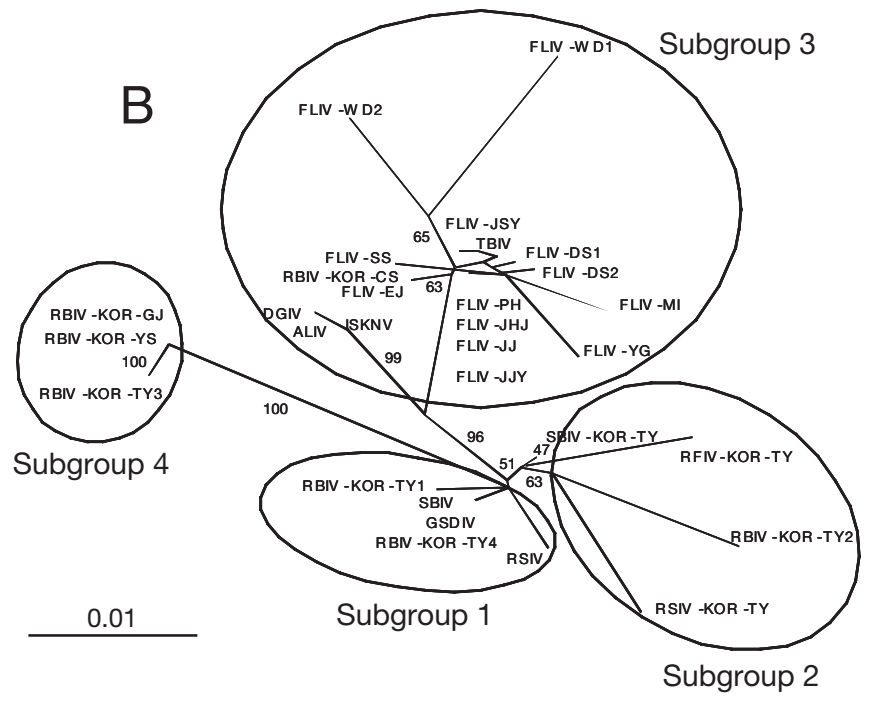

Fig. 3. Phylogenetic analysis of iridovirus major capsid protein (MCP). (A) Amino acid sequences of the MCP of 13 flounder isolates of iridovirus were compared with those from 31 iridoviruses. See Table 4 for GenBank accession numbers for the protein sequences and isolate abbreviations shown. (B) Phylogenetic position of iridovirus isolates of Group 4 from (A). The tree was derived by comparing the amino acid sequences of full-length 453 amino acids of MCP. GenBank accession numbers for protein sequences are the same as in (A). The numbers indicate the percentage bootstrap support for each node from 1000 replicates. The distances are proportional to the relative sequence deviations between individual amino acid sequences. The phylogenetic analyses were carried out using the ClustalW program 
group 4. Iridoviruses within group 4 could be further divided into 4 distinct subgroups (Fig 3B). While the 10 iridovirus strains isolated in 2000 and 2002 from rock bream, red sea bream, rockfish, and sea bass were segregated into 4 different subgroups, all of the 13 iridovirus strains isolated from flounder in 2003 were segregated into one subgroup, subgroup 3 (Fig. 3B).

The 13 fish farms were geographically distant from each other and included Jeju, an island located in the southernmost region of the Korean peninsula (Fig. 1). However, the epizootics occurred simultaneously both on the Korean mainland and on Jeju island; what is more, the 13 FLIVs showed 97 to $100 \%$ amino acid sequence identity to each other (Table 3). This suggests that all of the 13 isolates of iridovirus have a single origin. In Korea, there are several flounder hatcheries and eggs and juveniles from these hatcheries are frequently transferred to other fish farms over a wide area. Thus, it is highly possible that a strain of iridovirus had been introduced originally into one or a few flounder hatcheries and that the iridovirus may then have spread rapidly through a transfer of fish from one fish farm to another. At present, the origin of the iridovirus strains infecting flounders is uncertain. However, based on the MCP tree, we can speculate about the possible source of the 13 flounder isolates. Besides the 13 flounder isolates, there were 2 more iridovirus strains isolated in Korea within subgroup 3; RBIVKOR-CS from rock bream (GenBank accession number, AY532611) and turbot iridovirus (TBIV) (GenBank accession number, BAD12494). In addition, in subgroup 3, there were 3 foreign iridovirus strains; ISKNV from mandarin fish Synchiropus chuatsi, China (He et al. 2001), DGIV from dwarf gourami Colisa lalia, Malaysia, and ALIV from African lampeye Aplocheilichthys normani, Sumatra Island (Sudthongkong et al. 2002). In Korea, various species of fish are imported from foreign countries, especially from China and Japan, and more than 2 species of fish are commonly cultured in the same geographic locations; even in the same fish farm. It is likely, therefore, that an iridovirus strain was introduced into Korea via imported rock bream and/or turbot which then spread to flounders cultured in hatcheries by cross-species transmission.

In this study, we isolated 13 FLIVs which are the same species as RBIVs, RSIV, and ISKNV from diseased flounders during wide-spread epizootics in Korea. A phylogenetic analysis of the 13 FLIVs, based on the amino acid sequences of the MCP, revealed that all of the 13 FLIVs clustered within one group, a new genus, tentatively referred to as the cell hypertrophy iridoviruses. Recently, in Korea, we have observed a rapid spread of the iridovirus of this new genus among various species of cultured fish including rock bream, red sea bream, rockfish, sea bass as well as flounders. Thus, it seems urgent that a further spread of this iridovirus species to other fish species and other geographic regions be prevented and that reagents be developed to control iridoviral diseases in cultured fish.

Acknowledgements. This study was supported by a grant from the National Fisheries Research and Development Institute. J.S.K. was partly supported by the BK21 Program of the Korea Research Foundation.

\section{LITERATURE CITED}

Ahne W, Schlotfeldt HJ, Thomsen I (1989) Fish viruses: isolation of an icosahedral cytoplasmic deoxyribovirus from sheatfish (Silurus glanis). Zentralbl Vetmed Reihe B 36: 333-336

Darai G, Anders K, Koch HG, Delius H, Gelderblom H, Samalecos C, Flugel RM (1983) Analysis of the genome of fish lymphocystis disease virus isolated directly from epidermal tumours of pleuronectes. Virology 126:466-479

Do JW, Moon CH, Kim HJ, Ko MS, and 14 others (2004) Complete Genomic DNA Sequence of Rock Bream Iridovirus. Virology 325:351-363

Eaton BT, Hyatt AD, Hengstberger S (1991) Epizootic haematopoietic necrosis virus: purification and classification. J Fish Dis 14:157-169

Felsenstein J (1985) Confidence limits on phylogenies: an approach using bootstrap. Evolution 39:783-791

Goldberg TL, Coleman DA, Grant EC, Inendino KR, Philipp DP (2003) Strain variation in an emerging iridovirus of warm-water fishes. J Virol 77:8812-8818

He JG, Deng M, Weng SP, Li Z, Zhou SY, Long QX, Wang XZ, Chan SM (2001) Complete genome analysis of the mandarin fish infectious spleen and kidney necrosis iridovirus. Virology 291:126-139

Hedrick RP, McDowell TS (1995) Properties of iridoviruses from ornamental fish. Vet Res 26:423-427

Hedrick RP, McDowell TS, Ahne W, Torhy C, de Kinkelin P (1992) Properties of three iridovirus-like agents associated with systemic infections of fish. Dis Aquat Org 13:203-209

Hetrick FM, Hedrick RP (1993) New viruses described in finfish from 1988-1992. Annu Rev Fish Dis 3:187-207

Hyatt AD, Gould AR, Zupanovic Z, Cunningham AA, Hengstberger S, Whittington RJ, Kattenbelt J, Coupar BE (2000) Comparative studies of piscine and amphibian iridoviruses. Arch Virol 145:301-331

Jung SJ, Oh MJ (2000) Iridovirus-like infection associated with high mortalities of striped beakperch, Oplegnathus fasciatus (Temmink et Schlegel), in southern coastal areas of the Korean peninsula. J Fish Dis 23:223-226

Kim YJ, Jung SJ, Choi TJ, Kim HR, Rajendran KV, Oh MJ (2002) PCR amplification and sequence analysis of iridolike virus infecting fish in Korea. J Fish Dis 25:121-124

Langdon JS, Humphrey JD, Williams LM, Hyatt AD, Westbury HA (1986) First virus isolation from Australian fish: an iridovirus-like pathogen from redfin perch, Perca fluviatilis. J Fish Dis 9:263-268

Langdon JS, Humphrey JD, Williams LM (1988) Outbreaks of an EHNV-like iridovirus in cultured rainbow trout, Salmo gairdneri. J Fish Dis 11:93-96 
Moody NJG, Owens L (1994) Experimental demonstration of the pathogenicity of a frog virus, Bohle iridovirus, for a fish species, barramundi Lates calcarifer. Dis Aquat Org 18: 95-102

Page RDM (1996) TreeView: an application to display phylogenetic trees on personal computers. Comput Appl Biosci 12:357-358

Pozet F, Morand M, Moussa A, Torhy C, de Kinkelin P (1992) Isolation and preliminary characterization of a pathogenic icosahedral deoxyribovirus from the catfish Ictalurus melas. Dis Aquat Org 14:35-42

Saitou N, Nei M (1987) The neighbor-joining method: a new method for reconstructing phylogenetic trees. Mol Biol Evol 4:406-425

Sudthongkong C, Miyata M, Miyazaki T (2002) Iridovirus disease in two ornamental tropical freshwater fishes: African lampeye and dwarf gourami. Dis Aquat Org 48:163-173

Editorial responsibility: Jo-Ann Leong,

Kaneohe, Hawaii, USA
Thompson JD, Higgins DG, Gibson TJ (1994) CLUSTAL W: improving the sensitivity of progressive multiple sequence alignment through sequence weighting, position-specific gap penalties and weight matrix choice. Nucleic Acids Res 22:4673-4680

Tidona CA, Darai G (1997) The complete DNA sequence of lymphocystis disease virus. Virology 230:207-216

Williams $\mathrm{T}$ (1996) The iridoviruses. Adv Virus Res 46: $345-412$

Williams T, Cory J (1993) DNA restriction fragment polymorphism in iridovirus isolates from individual blackflies (Diptera: Simuliidae). Med Vet Entomol 7:199-201

Willis D (1990) Taxonomy of iridoviruses. In: Darai G (ed) Molecular biology of iridoviruses. Kluwer, Boston, MA, p $1-12$

Wolf K (1988) Fish viruses and fish viral diseases. Cornell University Press, Ithaca, NY

Submitted: May 3, 2004; Accepted: December 17, 2004

Proofs received from author(s): April 20, 2005 